\title{
HUMAN DIGNITY CONCEPTS IN JUDICIAL REASONING. STUDY OF NATIONAL AND INTERNATIONAL LAW ${ }^{1}$
}

\author{
Katarzyna Doroszewska*
}

\begin{abstract}
Many modern legal systems declare, that protection of human dignity plays an important role in its construction. Therefore, a question may be asked if the concept of dignity is similar in different legal systems. The following paper presents the results of the research on human dignity concepts in reasoning of national (Polish and German Supreme Courts) and international courts (ICC, ECHR). Both national systems provide a constitutional protection of human dignity, Rome Statute, which constitutes the ICC, prohibits behaviours infringing dignity (model of Geneva Conventions), whereas the European Convention of Human Rights does not include the term "human dignity", only prohibition of torture or "inhuman or degrading treatment", what is understood as protection of dignity. On the basis of the research there could be stated, that each legal system has developed its own concept of human dignity, although all concepts have a similar core, as nearly all ways of understanding "protection of human dignity" are combined with a commitment to respect each person. This kind of respect could be assumed as a basis of human dignity protection.
\end{abstract}

Keywords: human dignity, comparative law, international law

Katarzyna Doroszewska, M.A., Research Associate, Faculty of Law and Administration, Jagiellonian University in Kraków; correspondence address: ul. Olszewskiego 2, 31-007 Kraków, Poland; e-mail: katarzyna.doroszewska@uj.edu.pl; https://orcid. org/0000-0002-3214-2535.

1 Study financed from the budget for years 2017-2021 as research project within the program „Diamentowy Grant”; Part of the results of the study has been presented at the IVR 2019 Special workshop on "The Role of Human Dignity in Criminal Law and Ethics in the Age of Pluralism". 


\section{INTRODUCTION}

Human dignity is considered as one of the most precious values in the modern world. It is protected by a majority of legal systems, both national and international. Although in many legal acts one may find an obligation to protect dignity, none of those acts contains its definition. As the consequence of this situation, the meaning of "human dignity" remains unclear and may cause misunderstandings.

The concept of "human dignity" has been a problem for a long time not only for lawyers, but also for philosophers. The main question about "human dignity" is its unclear meaning and its position as an important value or basis of other rights ${ }^{2}$. According to this statement, human dignity should be protected in every possible situation, not only as an exception, so there should exist some rules of legal protection. For effective legal protection, there should exist a precise way of understanding this term. What is making this consideration even harder, is that every legal system is different. Therefore, there could exist thousands of human dignity concepts if every court builds its own interpretation. These concepts could be totally different or very similar depending on court's concepts. Some would argue, that there is a universal meaning of the human dignity concept, called sometimes a minimum core of human dignity. Main issue in "minimum core" of human dignity would be "intrinsic worth of the person" which is property of every human without exceptions ${ }^{3}$. To verify if this thesis is true, all legal systems should be analysed in perspective of the meaning of human dignity.

In the following paper there will be presented the most important ways of understanding the term "human dignity" in the judgements of international criminal tribunals (ICC, ICTY, ICTR), the European Court of Human Rights and criminal chambers of supreme courts in Germany and Poland (Bundesgerichtshof and Sąd Najwyższy). The International Crimi-

2 Understanding dignity as basis for other human rights can be found in German Basic Law or Polish constitution.

3 Christopher McCrudden, "Human Dignity and Judicial Interpretation of Human Rights", The European Journal of International Law 19, no. 4 (2008): 679, https://doi. org/10.1093/ejil/chn043. 
nal Court is based on the Rome Statute, which evokes the phrase "human dignity" in art. 8 and art. 68. This court decides in most important criminal cases in international society and on some level influences on decisions of national courts. Taking into account international role of these courts, in the matter of criminal law, it couldn't be omitted.

The European Court of Human Right is a court for all European cases in which human rights could have been infringed. This court is based on the European Convention of Human rights, which does not contain the term "human dignity". Nevertheless, the Court relatively often refers to the term "human dignity" in its judgements. The ECHR is not a criminal court, but very often decides in cases connected with criminal law, such as conditions in prisons or punishments. This institution is considered a big authority in European law and ECHR judgments have great influence on national jurisdictions.

Besides the ICC and ECHR in following paper will be presented two national courts - Polish and German. Constitutional regulations in both countries protect human dignity. Both German Basic Law and Polish Constitution use similar wording, as Polish Constitution was partially inspired by German text. German Basic Law is very significant, as it was the first constitution after World War II which ensured the protection of dignity. In that time, it was supposed to prevent the cruelty that happened during the war. This document inspired many legislators in other countries in the area of human rights protection.

As was said before, protection of human dignity is an important part of the legal system. But how can we say if the protection is sufficient? Is it possible to infringe dignity and what would it look like? Such questions are focused on a practical side of law, not on a theoretical concept of constitutional law. Essential is the meaning of such protection for non-lawyers who could be participating in some cases. The answer to this question could be found in judgments of courts. Judicial understanding of this term could give the answer how the protection of dignity looks. Research including international and national judgements could also give a clue on an issue of plurality of dignity concepts in an international perspective.

The following research was focused on a meaning of dignity in the area of criminal law. The concept of dignity seems to have essential meaning in the criminal law, because concept of human dignity influences on all fields 
of law, including criminal law. Also, the nature of criminal law is specific, as it is concerning subtle issues of punishment which could infringe one's freedom. However, important is not only the way of understanding "human dignity", but also whether the obligation of dignity protection influences proceedings and given judgments. In other words, what does it mean for individuals, that their dignity is protected in criminal law? Of course, criminal cases are usually not the subject of constitutional court's reasoning, but of state supreme courts - in the case of Germany and Poland - Bundesgerichtshof (BGH) and Sad Najwyższy (SN) in their criminal chambers.

\section{INTERNATIONAL COURTS}

\section{1. International criminal tribunals (ICC, ICTY, ICTR)}

In the area of criminal law the reasoning of the International Criminal Court should be especially important. This court decides on cases with enormous importance in the world, like genocide or crimes against the humanity. Conduct judged by the ICC could be as well judged by national courts, if they ensure adequate conditions of the process. That is the reason why ICC judgments could have an influence on judgments of other criminal courts. In the matter of international criminal law, the status of "human dignity" is slightly different than in other legal systems. In the Rome Statute there are a few articles concerning "human dignity" Article 8 and Article 68(1). Both these articles consider dignity in similar, yet not identical way. As the ICC was formed of the basis of experience of other international criminal tribunals and to some point is a continuation of two other tribunals, also the judicial experience of ICTR and ICTY should be analysed in this perspective.

As the Article 8 of Rome Statute states, one form of war crime is "Committing outrages upon personal dignity, in particular humiliating and degrading treatment". Worth mentioning is the fact, that this fragment is identical with common Article 3 of four Geneva conventions, 
which prohibits such conducts against certain groups of people ${ }^{4}$, what only underlines that war crimes are usually interpreted in the view of these Conventions. The interpretation of this type of crime should be consistent with its previous understanding, also in the ICTY and ICTR judgements.

The aim of artical 3 of the Geneva Conventions was to protect human dignity and ensure human treatment to all people "without any adverse distinction founded on race, colour, religion or faith, sex, birth or wealth, or any other similar criteria"s. The protection of human dignity could be implemented in law in positive and negative ways as an obligation to human treatment or prohibition of infringing the value. Instead of obligation to such treatment, conventions contain the list of prohibited behaviours, what was assumed as a more flexible solution ${ }^{6}$. In practice, the list of behaviours is only a little bit more precise than the general obligation. Therefore, the courts still had to define the sense of "outrage upon human dignity".

As the ICTY has stated in the case of Aleksovski vs. The Prosecutor "An outrage upon personal dignity within Article 3 of the Statute is a species of inhuman treatment that is deplorable, occasioning more serious suffering than most prohibited acts falling within the genus." and "the act must cause serious humiliation or degradation to the victim. It is not necessary for the act to directly harm the physical or mental well-being of the victim. It is enough that the act causes real and lasting suffering to the

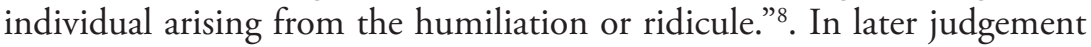
the ICTY argued, that crime does not have any temporal requirement, so the effect doesn't have to be "lasting"'.

4 ICC, Judgment of 22 March 2016, Prosecutor v. Bosco Ntaganda, Case No. ICC01/04-02/06 OA 2, icc-cpi.int, 30.

5 The International Committee of the Red Cross, Geneva Conventions of $12 \mathrm{Au}-$ gust 1949, Common Article 3.

6 ICTY, Trial Chamber Judgment of 25 June 1999, Prosecutor v. Zlatko Aleksovski, Case No.: IT-95-14/1-T, icty.org, 49.

ICTY, Trial Chamber Judgment of 25 June 1999, Prosecutor v. Zlatko Aleksovski, Case No.: IT-95-14/1-T, icty.org, 54.

8 ICTY, Trial Chamber Judgment of 25 June 1999, Prosecutor v. Zlatko Aleksovski, Case No.: IT-95-14/1-T, icty.org, 56.

9 ICTY, Trial Chamber Judgement of 22 February 2001, Prosecutor v. Dragoljub Kunarac, Radomir Kovac and Zoran Vukovic, Case No.:IT-96-23-T\&IT-96-23/1-T, icty.org, 501. 
The Court considers the prohibited behaviour as humiliation and degradation. Behaviours considered by the Court as "outrage upon dignity" had mostly a social context and were connected with public humiliation ${ }^{10}$. The treatment was damaging the victim's social status and was bound with great shame or deprivation of respect in society ${ }^{11}$. In some cases, the behaviour had specific meaning in a concrete social group and humiliation had a religious context.

It is clear that the level of suffering in such cases is strictly connected to individual sensibility of the victim. Additionally, the Court was looking for more objective criterium of infringement. It stated, that "the humiliation must be so intense that the reasonable person would be outraged"12. Objective criterium is necessary in judging the infringement of human dignity, as also the victim need not to be personally aware of a humiliation, but it is sufficient if the humiliation is recognized objectively. According to the Elements of Crime, such judgement should take on the account also the cultural background of the situation ${ }^{13}$. Both subjective and objective elements should be taken into account ${ }^{14}$.

None of the criminal tribunals gives a definition of behaviour which could be considered as an outrage against humanity, but it is decided in

10 Examples: 'Prosecuting War Crimes of Outrage upon Personal Dignity Based on Evidence from Open Sources - Legal Framework and Recent Developments in the Member States of the European Union', Genocide Network Secretariat EUROJUST, 2014, http:/www.eurojust.europa.eu/doclibrary/genocide-network/KnowledgeSharing/Prosecuting $\% 20$ war $\% 20$ crimes $\% 20$ of $\% 20$ outrage $\% 20$ upon $\% 20$ personal $\% 20$ dignity $\% 20$ based $\% 20$ on $\% 20$ evidence $\% 20$ from $\% 20$ open $\% 20$ sources $\% 20($ February $\% 202018) / 2018$ 02_Prosecuting-war-crimes-based-on-evidence-from-open-sources_EN.pdf.

11 'Prosecuting War Crimes of Outrage upon Personal Dignity Based on Evidence from Open Sources - Legal Framework and Recent Developments in the Member States of the European Union'.

12 ICTY, Trial Chamber Judgment of 25 June 1999, Prosecutor v. Zlatko Aleksovski, Case No.: IT-95-14/1-T, icty.org, 56, similarly: ICTY, Appeal Chamber Judgement of 12 June 2002, Prosecutor v. Dragoljub Kunarac, Radomir Kovac and Zoran Vukovic, Case No.:IT-96-23-T\&IT-96-23/1-T, 501, 162.

13 Elements of Crime, (The Hague: International Criminal Court, 2011), Article 8(2) (b) $(\mathrm{xx}), \S 1$, fn. 49.

14 ICTY, Trial Judgment of 2 November 2001, Prosecutor v. Miroslav Kvočka Milojica Kos, Mlado Radic, Zoran Zigic, Dragoljub PrcacKamilojica Kosmla Case No.: IT-9830/1, icty.org 167. 
specific cases. Consequently, there could arise a problem of classification of conduct such as rape or other sexual conduct, especially if the victim was imprisoned or the conduct has a public or especially humiliating character, as in the Furundzija case ${ }^{15}$. In view of the Prosecutor in the Kunarac case, rape could be assumed as an outrage against humanity, but for the clarity of the process and to avoid cumulative conviction problems, this conduct should be prosecuted separately ${ }^{16}$.

As was said before, rape could be assumed in some situations as an outrage against dignity. Other conducts such as prisoning people in harsh condition, demoralizing treatment ${ }^{17}$, or other "serious humiliating and degrading treatment" such as "beating, rape and sexual assault, harassment, humiliation and psychological abuse, and confinement, in inhumane conditions"18, forcing someone to walk in front of the soldiers without underwear ${ }^{19}$ and many other, also could be acknowledged as outrage against dignity. Importantly, the Rome Statute protects human dignity even after death of the person, so the corpse could be an object of this crime ${ }^{20}$.

The crime of outrage against dignity is not the only institution in the Rome Statute concerning dignity. Also, Article 68 (1) of the Statute contains the obligation to protect witnesses' dignity. The justification of the existence of this article seems to be clear - being a witness is hard for all

15 ICTY, Trial Judgment of 10 December 1998, Prosecutor v. Anto Furundzija, Case No.: IT-95-17/1-T, icty.org, 272.

16 ICTY, Trial Chamber Judgement of 22 February 2001, Prosecutor v. Dragoljub Kunarac, Radomir Kovac and Zoran Vukovic, Case No.:IT-96-23-T\&IT-96-23/1-T, icty. org, 554.

17 ICTY, Trial Judgment of 2 November 2001, Prosecutor v. Miroslav Kvočka Milojica Kos, Mlado Radic, Zoran Zigic, Dragoljub PrcacKamilojica Kosmla Case No.: IT98-30/1, icty.org, 191; ICTY, Trial Chamber Judgement of 22 February 2001, Prosecutor v. Dragoljub Kunarac, Radomir Kovac and Zoran Vukovic, Case No.:IT-96-23-T\&IT-9623/1-T, icty.org, 501.

18 ICTY, Trial Judgment of 2 November 2001, Prosecutor v. Miroslav Kvočka Milojica Kos, Mlado Radic, Zoran Zigic, Dragoljub PrcacKamilojica Kosmla Case No.: IT-9830/1, icty.org, 171-173.

19 ICC, Decision on the confirmation of charges of 30 September 2008, Prosecutor v. Germain Katanga, Mathieu Ngudjolo Chui, Case No.: ICC-01/04-01/07, icc-cpi.int, 375.

20 Elements of Crime, (The Hague: International Criminal Court, 2011), Article 8(2) (b) $(\mathrm{xx}), \$ 1$, fn. 49 . 
victims of crime and conduct judged by the ICC could be much more traumatic for them. The aim of proceeding should not cause more harm to the victims, so the Court should act with compassion for victims, not only in reasoning and sentencing but especially during the proceedings.

The basic meaning of Article 68 (1) is to protect victims from humiliation or another psychological or physical harm. Therefore, sometimes the ICC decides to protect victim's identity or location, justifying it with the need to protect his or her dignity ${ }^{21}$. Article 68 (1) is for the Court an obligation, so the Court itself must take into account the vulnerability of witnesses, and sometimes decide, that some statements are inadmissible during the hearing 22 .

There are cases, in which victims have influence on the admissibility of evidence. In one of them ${ }^{23}$ the Court decided about the Victims' Observations and granted victims the right "to lead evidence pertaining to the guilt or innocence of the accused, and to challenge the admissibility or relevance of evidence in the trial proceedings." which concerns, among others, the evidence, that could be "harmful" to their dignity ${ }^{24}$.

Other meaning of "dignity" in ICC documents is served by witnesses and victims. In their statements they share their thoughts and their feelings about the conduct. Sometimes they state, that they felt deprived of dignity, or that their dignity had been damaged ${ }^{25}$. That meaning, although not legal, is very interesting as it shows the intuitive understanding of "dignity" - partly as the aspect of social status, partly as self-esteem. What should

21 ICC, Decision on requests to present additional evidence and submissions on sentence and scheduling the sentencing hearing of 4 May 2016, Prosecutor v. Jean-Pierre Bemba Gombo, Case No.: ICC-01/05-01/08-3384, icc-cpi.int, 39.

22 The Court had to reject some statements on the basis, that witnesses hadn't been informed about parties intention to rely on their statements. ICC, Decision on the confirmation of charges of 29 January 2007, Prosecutor v. Thomas Luganga Dyilo, Case No.: ICC-01/04-01/06, icc-cpi.int, 58-59.

23 ICC, Appeal Judgment of 11 July 2008, Prosecutor v. Thomas Luganga Dyilo, Case No.: ICC-01/04-01/06 OA 9 OA 10, icc-cpi.int, 103-105.

24 ICC, Appeal Judgment of 11 July 2008, Prosecutor v. Thomas Luganga Dyilo, Case No.: ICC-01/04-01/06 OA 9 OA 10, icc-cpi.int, 103-105.

25 ICC, Decision on Sentence pursuant to Article 76 of the Statute of 21 June 2016, Prosecutor v. Jean-Pierre Bemba Gombo, Case No.: ICC-01/05-01/08 icc-cpi.int, 38-39. One of the witnesses said even „we have no value”. 
be pointed out, is that the conduct that resulted in depriving dignity in the victims' view could be described as "humiliating". According to the Court's decision humiliating behaviour is behaviour infringing dignity. That implies, that respect for the person is the constitutional part of dignity.

Another source of understanding dignity in reasoning of the ICC are decisions about reparations. In these documents, it is stated, that the perpetrator's conduct had humiliated the victim and through this had damaged her or his dignity. The reparation should enable victims to recover their dignity ${ }^{26}$. In the decision-making process, the Court should respect the victims' dignity ${ }^{27}$. The Court takes into account not only the social status in the group, but also the individual feeling of humiliation and damage of dignity, such as individual feeling about their family's death and the indignity of burial ("the impossibility of burying corpses, the indignity of burials not performed in keeping with the rites and customs of the people in question") ${ }^{28}$.

On the basis of the International Criminal Courts' reasoning it could be stated, that "outrage against human dignity" is an infringement bound with damages on social status (as the victim could be considered as "dirty" after rape), serious humiliation or victim's moral system (as enforcing victim to immoral behaviour). It has more in common with internal well-being of the victim than physical pain (thus of course it is often connected). Dignity is damaged if the reasonable observer considers behaviour as humiliating in the moment of conduct. Also, the social background of both the victim and the perpetrator could be important for judgement, as one behaviour could be considered as more humiliating or causing more damage in different cultures ${ }^{29}$.

The ICTY has acknowledged the protection of human dignity understood as an aspect of personality as one of the basic values in modern

26 ICC, Reparations Order of 17 August 2017, Prosecutor v. Ahmad Al Faqi Mahdi, Case No.: ICC-01/12-01/15, icc-cpi.int, 28.

27 ICC, Reparations Order of 17 August 2017, Prosecutor v. Ahmad Al Faqi Mahdi, Case No.: ICC-01/12-01/15, icc-cpi.int, 32.

28 ICC, Order for Reparations pursuant to Article 75 of the Statute of 24 March 2017, Prosecutor v. Germain Katanga, Case No.: ICC-01/04-01/07, icc-cpi.int, 231.

29 ICC, Decision on Sentence pursuant to Article 76 of the Statute of 21 June 2016 Prosecutor v. Jean-Pierre Bemba Gombo, Case No.: ICC-01/05-01/08, icc-cpi.int, 38-39. 
human rights law. It stated "it is difficult to conceive of a more important value than that of respect for the human personality. It can be said that the entire edifice of international human rights law, and of the evolution of international humanitarian law, rests on this founding principle" ${ }^{30}$. Part of this concept is granting victims the right to satisfactory participation in the process. Therefore, a victim should testify in appropriate conditions and have the right to present evidence.

\section{2. EUROPEAN COURT OF HUMAN RIGHTS}

While the ICC is an international court, working on cases from all around the world, the ECHR works only on European cases on the basis of the European Convention of Human Rights. This convention itself is a very specific document among other international treaties. In this convention, there is no expression "human dignity", what is very rare in the post-war world. Some of the authors of the Convention admitted, that it was an intentional decision as the authors wanted to create a practical system, not to start another war for values, what was especially significant in the time of the Cold War ${ }^{31}$. Before the 2002 the term "human dignity" has not been used in the system of documents connected with the ECHR. For the first time it appeared in the Preamble to the Additional Protocol no. 13 about abolishing the death penalty.

However, the Court uses the expression "human dignity", even though it is not included in the Convention. Up to this date (January 2020) 1060 judgments containing the phrase "human dignity" can be found in the ECHR database. For the reasoning of the ECHR, "human dignity" is one of the most important values, even though some could argue that it has no normative meaning due to its absence in the Convention.

30 ICTY, Judgment of 25 June 1999, Prosecutor v. Zlatko Aleksovski, Case No.: IT95-14/1-T, icc-cpi.int, 54.

31 Antoine Buyse, "Dignified Law: The Role of Human Dignity in European Convention Case-Law, Keynote Delivered on 11 October 2016, at Utrecht University", The ECHR Blog, October 21, 2016, http://echrblog.blogspot.com/2016/10/the-role-of-human-dignity-in-echr-case.html. 
According to A. Buyse, "dignity" in judgments of the ECHR could be used in differentiated meanings as "(1) the specific rights to which it is mostly applied; (2) the way it differentiates according to the specific facts and context of a case; (3) the role it plays in the legal argument" ${ }^{\prime \prime 2}$.

The ECHR uses "dignity" mostly concerning human rights which are assumed as basic or "core" like "the right to life, the prohibition of torture and inhuman and degrading treatment, and finally the prohibition of slavery and servitude." 33 . The Court assumes that prohibition of torture and inhuman treatment is bound with dignity ${ }^{34}$. According to the Court, the link between Article 3 and human dignity is so strong, that it is impossible to analyse this article without evoking the concept of human dignity. As the Court has emphasized in its judgments, the aim of Article 3 was to protect dignity, which could be interfered by "degrading" treatment, which is not necessarily based on a physical violence ${ }^{35}$.

The majority of the analysed judgments, which use the expression "human dignity" or "dignity" were concerned on conditions of imprisonment. The Court had stated, that "Where a person is deprived of his liberty, the State must ensure that he is detained under conditions which are compatible with respect for his human dignity and that the manner and method of the execution of the measure do not subject him to distress or hardship exceeding the unavoidable level of suffering inherent in detention" ${ }^{36}$. This opinion is often repeated in ECHR judgments. Judgements of the ECHR in cases of imprisonment could be divided into two main groups - concerning physical conditions in prisons and on imprisonment itself.

In the group focusing on imprisonment, there should be a distinction in judgments about the punishment of imprisonment, especially about life

32 Antoine Buyse, "Dignified Law: The Role of Human Dignity in European Convention Case-Law, Keynote Delivered on 11 October 2016, at Utrecht University”.

33 Antoine Buyse, "Dignified Law: The Role of Human Dignity in European Convention Case-Law, Keynote Delivered on 11 October 2016, at Utrecht University".

34 ECtHR Judgement of 28 September 2015 Case Bouyid v. Belgium, application no. 23380/09, hudoc.int, 81 .

35 ECtHR Judgement of 28 September 2015 Case Bouyid v. Belgium, application no. 23380/09, hudoc.int, 90.

36 ECtHR Judgement of 19 February 2009, Case A. and others v. The United Kingdom, application no. 3455/05, hudoc.int, 128. 
imprisonment without prospect of reduction or earlier release and other judgments. As the ECHR has stated, some types of punishment is not allowed under regulations of the Convention and can be treated as a violation of Article 3. The perspective of irreducible punishment can induce serious mental health problems ${ }^{37}$.

Also, specific conditions are given to the imprisonment of children and juveniles. On the basis of diverse international documents, the Court has stated, that this groups of detainees should be treated with respect to their dignity. On the basis of art. 3 of the Convention as well as on the basis of other international covenants, the State should ensure medical care for all detainees, also juveniles ${ }^{38}$. When the State fails to fulfil these conditions or the detainee doesn't get necessary medical care, it is a situation of inhuman treatment.

Police officers are obliged to respect detainees' dignity, "any recourse to physical force which had not been made strictly necessary by the person's own conduct diminished human dignity and was in principle an infringement of the right set forth in Article 3 "39. It seems to be obvious, but in such situations the detainee is in much more uncomfortable position than the state officer, because he is dependent on the officer's reaction. What can be surprising, the Court stated, that the rule from Article 3 of the Convention prohibiting inhuman or degrading treatment or punishment has no exceptions, even in the state of serious danger like a terroristic $\operatorname{attack}^{40}$. On the one hand, this statement confirms that the protection of dignity is unconditional (as Article 3 protects the value of dignity), on the other hand it seems to be inconsistent with the previous statement, that any unjustified recourse to physical force is prohibited, which raises questions about the permissibility of justified use of physical force. Does it mean that if a detainee provokes such behaviour of the police officer,

37 ECtHR Judgement of 19 February 2009, Case A. and others v. The United Kingdom, application no. 3455/05, hudoc.int, 129.

38 ECtHR Judgement of 23 March 2016, Case Blokhin v. Russia, application no. 47152/06, hudoc.int, 27, 136, 138, 140 .

39 ECtHR Judgement of 28 September 2015 Case Bouyid v. Belgium, application no. $23380 / 09$, hudoc.int, 56.

40 ECtHR Judgement of 28 September 2015 Case Bouyid v. Belgium, application no. $23380 / 09$, hudoc.int, 81 . 
he waives the protection of his dignity? Or that only unjustified attack is harmful for dignity? If the first option is correct, it means that the protection of dignity is not unconditional, but exist only if the person wants it. If the second one, it is inconsistent with whole understanding of dignity, as the same conduct could be diminishing or not, depending on previous behaviour of the other party, what causes reasonable doubts about the sense of the institution. The court itself doesn't give the answer, as it says, that significant is the fact that "treatment humiliates or debases an individual, showing a lack of respect for or diminishing his or her human dignity, or arouses feelings of fear, anguish or inferiority capable of breaking an individual's moral and physical resistance" 41 . What is more, it is sufficient if the victim is humiliated in his/her own eyes ${ }^{42}$. However, every situation is unique and should be analysed separately, taking into account all of circumstances. If the infringement is strictly connected with an unlawful behaviour of the prisoner as in the previous analysed example, it would be unfair to consider police officers as guilty of depriving dignity, when the prisoner decided to behave in such way and had to predict the reaction of officers.

According to the court, human dignity could be infringed by degrading or humiliating conduct. Such behaviour should be recognized objectively, it could not depend on the individual's feeling ${ }^{43}$. The subjective feeling of harm would be important but is not a necessary state if the conduct was legally admissible. In view of $\mathrm{N}$. Mavronicola it is rather the matter of "wrong" than "harm" 44 , what could be helpful in the process of delimitation of wrongful behaviour. This perspective presumes, that this kind of "wrong" is objective and clear. Similarly, A. Buyse believes, that the argument of "human dignity" helps the Court distinguish between permissible

41 ECtHR Judgement of 28 September 2015 Case Bouyid v. Belgium, application no. 23380/09, hudoc.int, 87.

42 ECtHR Judgement of 28 September 2015 Case Bouyid v. Belgium, application no. 23380/09, hudoc.int.

43 ECtHR Judgement of 28 September 2015 Case Bouyid v. Belgium, application no. 23380/09, hudoc.int, 101; Natasa Mavronicola, "Bouyid and Dignity's Role in Article 3 ECHR,” Strasbourg Observers (blog), October 8, 2015, https://strasbourgobservers. com/2015/10/08/bouyid-and-dignitys-role-in-article-3-echr/.

44 Natasa Mavronicola, "Bouyid and Dignity's Role in Article 3 ECHR". 
and prohibited behaviour ${ }^{45}$. In practice, important would be to judge the case in the perspective of treating a person with special respect (contrary to objects or animals) or providing proper conditions to develop personality ${ }^{46}$.

Moreover, human dignity plays another important role in the legal system of the ECHR - as way to enrich a discourse and offer opening the system to natural law. As said A. Buyse: "human dignity may be a rhetorical linchpin between societal understandings of what is humane and what carries moral stigma on the one hand and the hard black-letter approach of law on the other" ${ }^{27}$. It is important to open positive law to extra-legal values such as human dignity. As a result, specific behaviour doesn't have to be prohibited in particular, but the judge of the ECHR could assume it as such, using protection of human dignity as argumentative tool. It also increases the feeling of social justice, if the victim could evoke protection of his/her dignity, which is commonly known value.

\section{MEANING OF "HUMAN DIGNITY" IN REASONING OF NATIONAL COURTS}

\subsection{Bundesgerichtshof (BGH)}

German Grundgesetz has an opinion of one of the most significant legal acts in the matter of human dignity protection. After its entry into force it has become the model legislation in this issue. Many younger legal acts have been made on the basis of this act. Grundgesetz have been created in a specific time, shortly after the Second World War, when many people were shocked by the cruelty done by people to people. Common reaction was to prevent such events, also by the law. That is the reason why dignity protection was placed at the first place in Grundgesetz, and it cannot be changed.

45 Antoine Buyse, "Dignified Law: The Role of Human Dignity in European Convention Case-Law, Keynote Delivered on 11 October 2016, at Utrecht University”.

46 Natasa Mavronicola, „Bouyid and Dignity's Role in Article 3 ECHR”.

47 Antoine Buyse, 'Dignified Law: The Role of Human Dignity in European Convention Case-Law, Keynote Delivered on 11 October 2016, at Utrecht University'. 
The German Bundesgerichtshof (German Supreme Court) is not only the court but also an institution, that should resolve doubts about legal interpretation. Therefore, its reasoning is more important than a sole decision. That is the cause why its judgments should be analysed as it sets the line of interpretation for all courts in Germany.

Most of the BGH judgments are related to the way of treating people. In one case, the BGH has decided that even the consent of the harmed person cannot justify the harm of dignity and treating people in an undignified manner ${ }^{48}$. Some judgments of the BGH concerned the boundary between dignity and punishment. The penalty should be compatible with human dignity protection. In addition, BGH had decided that the length of the punishment of imprisonment should protect the realistic chance of regaining freedom. Otherwise, the punishment infringes human dignity ${ }^{49}$.

The principle of compatibility of the penalty with the principle of human dignity protection is also applicable to the way of administering punishment. According to the $\mathrm{BGH}$, punishment should be related to the specific criminal conduct. Therefore, the court should precisely determine the alleged conduct in the indictment. Therefore, alternative description of conduct both in indictment and judgment is inappropriate, as it results in a state of uncertainty ${ }^{50}$.

In some judgments the BGH decides about freedom of speech and personal dignity. It has decided, that also dignity of a social group could be infringed by defamation. It is especially important in case of incitement to hatred, as in Germany Volksverhetzung $g^{51}$. This decision is particularly interesting, because usually the personal dignity is concerned as an attribute or aspect of an individual, not of a group. In the mentioned decision, the BGH has affirmed, that also feelings of social groups are worth protection.

48 German Supreme Court, Resolution of 24 October 2018, Ref. No. 1 StR 212/18, 11.

49 This reasoning is applied not only in case of punishment life imprisonment without prospect of reduce or earlier release, but also in cases of relatively short imprisonment that is still longer than estimated life length of the detainee. BGH Resolution of 25 January2018, Ref. No. 3 StR 613/17, 3.

50 German Supreme Court Resolution of 11. March 2015, Ref. No. 2 StR 495/12, 56.

51 German Supreme Court Resolution of 30 October 2018, Ref. No. 3 StR 167/18, 6. 
The expression "human dignity" in the judgments of the BGH has broader meaning, as it appears in cases of "typical" crimes, such as murder or theft. In one of these cases, the BGH gave nearly a definition of harm done to the human dignity, stating, that it is the conduct, which attacks the core of one's personality ${ }^{52}$. The conduct should also suggest, that the worth of one's life is significantly lower than others. That is a very important statement, because it enables application of the rule of human dignity protection in many cases, not limiting it to the cases of defamation or insult. The deciding element in the situation should be the way of infringement and the possible attack on one's personality. Moreover, this way of understanding dignity relates to two basic views of dignity - human and personal dignity, as it assumes an attack on the core of someone's personality in such manner. The first element relates to human dignity, the core of being a human, the second to personal dignity, as the conduct could be judged objectively as diminishing behaviour.

In similar way the BGH states that no one should be treated as an object of political actions. If state organs disregard a person's individuality and dignity, it would be unlawful ${ }^{53}$.

\subsection{Sąd Najwyższy (SN)}

Article 30 of the Polish Constitution contains an obligation of dignity protection, similar to the German Grundgesetz. Like in Germany, the Polish legal system belongs to civil law systems and every legal act must be consistent with the Constitution, criminal law acts and judgments. In the matter of criminal law, most difficult cases are viewed by the Sad Najwyższy (SN), the Polish Supreme Court. The SN in the last 18 years had only a few times used the expression "human dignity" in criminal cases.

Most of the cases concern the crime of defamation, (Article 212 of Polish Criminal $\operatorname{Code}^{54}$ ) and the connection between this crime and freedom

52 German Supreme Court Judgement of 27 July 2017, Ref. No. 3 StR 172/17, 31.

53 German Supreme Court, Resolution of 25 March 2015, Ref. No. 4 StR 525/13, 14.

54 Article $212 \$ 1$ Polish Criminal Code of 6 June 1997, Journal of Laws 2020, No. 1444 („Whoever imputes to another person, a group of persons, an institution or organisational unit not having the status of a legal person, such conduct, or characteristics that may discredit them in the face of public opinion or result in a loss of confidence neces- 
of the press. First of all, the $\mathrm{SN}$ in these cases uses "dignity" in its social aspect, meaning the respect within the group or self-esteem. It is especially important in this type of crime. Conflict between press freedom and respect for personal goods is a universal problem. The $\mathrm{SN}$ stated that press freedom doses not have an absolute character and the protection of personal goods has privilege ${ }^{55}$. It does not mean, that the press cannot state anything that infringes one's personal dignity, but these statements cannot be false.

In some situations, the insult could be harmful not only to one person, but also to the group of people (as in the Article 257 of Polish Criminal Code ${ }^{56}$ ). It is interesting, because this type of crime typically touches individual persons, and protects the personal, individual dignity. The $\mathrm{SN}$ stated, that statements could be also harmful for dignity of a group ${ }^{57}$. In the case of defamation of a state officer, the $\mathrm{SN}$ states, that the protected value is the dignity of this officer (besides the functioning of public institutions $)^{58}$.

\section{CONCLUSIONS}

Courts are using the expression "human dignity" in different ways and in different meanings. What is interesting, the ECHR uses this expression a lot, even though there is no statement "human dignity" in Convention

sary for a given position, occupation or type to activity shall be subject to a fine, the penalty of restriction of liberty or the penalty of deprivation of liberty for up to one year"). https:// www.imolin.org/doc/amlid/Poland_Penal_Code1.pdf [25.01.2020].

55 Polish Supreme Court, Judgment of 6 December 2005, Ref. No. I CK 204/05, unreported, 11.

56 Article 257 Polish Criminal Code of 6 June 1997, Journal of Laws 2020, No. 1444 (,Whoever publicly insults a group within the population or a particular person because of his national, ethnic, race or religious affiliation or because of his lack of any religious denomination or for these reasons breaches the personal inviolability of another individual shall be subject to the penalty of deprivation of liberty for up to 3 years"). https://www. imolin.org/doc/amlid/Poland_Penal_Code1.pdf [25.01.2020].

57 Polish Supreme Court, Resolution of 17 August 2016, Ref. No. IV KK 53/16, unreported, 7.

58 Polish Supreme Court, Judgment of 22 June 2017, Ref. No. IV KK 194/17, unreported, 4 . 
and the meaning of "human dignity" is mostly created in judgments. At the state level, both German and Polish supreme courts use this expression, but in slightly different ways.

From different types of judgments, it could be concluded, that basic meanings of "human dignity" in different courts have much in common. It is consistent with the theory of $\mathrm{C}$. McCrudden, who claims, that the central idea of human dignity is universal, at least in European culture ${ }^{59}$

Another conclusion from the presented analysis is that only some courts are developing the concept of dignity. On the other hand, the ICC just like the state courts decides about the situation of an individual, but refers to dignity relatively rarely and in specific situations. It could be the consequence of the fact, that national courts are based on state constitutions, which often assume dignity as the most important value and basis of the system, whereas the ICC is based on the Rome Statute, in which "human dignity" is treated only as evoking the text of the Geneva Conventions and its Common Article 3.

Comparing two national courts is interesting, because both German and Polish constitutions include the article about protection of dignity, but judgements of the SN and the BGH are different. The $\mathrm{SN}$ focuses on the meaning of dignity in cases of defamation, nearly without reflections about human dignity as inherent and not disposable, whereas the BGH has some concept about understanding human dignity.

After this study, it seems to be clear, that there is no clear concept of dignity at the state and international level. Every court has its own concept, which was developed through years. However, all courts are using the expression "human dignity" in a quite similar way, mostly in cases of disrespect, defamation or harsh treatment. Among other meanings, courts understand infringement of the dignity, when person is treated as an object, or is forced to live in really poor conditions (especially during imprisonment). All of them take into consideration the individual feeling of an infringement of social status or self-esteem.

As it was pointed out, besides differences, some similarities in understanding "human dignity" can be found. As C. McCrudden stated, the

59 Christopher McCrudden, "Human Dignity and Judicial Interpretation of Human Rights", 675. 
core of understanding human dignity remains the same or very similar in acknowledging the worth of every human being ${ }^{60}$. The most basic and most general meaning of human dignity as in every understanding dignity is connected with respect for another person and the universal value of a human, independent from his personal situation.

\section{REFERENCES:}

Buyse, Antoine. „Dignified Law: The Role of Human Dignity in European Convention Case-Law, keynote delivered on 11 October 2016, at Utrecht University.” The ECHR Blog. October 21, 2016. http://echrblog.blogspot. com/2016/10/the-role-of-human-dignity-in-echr-case.html.

Mavronicola, Natasa. 2015. „Bouyid and dignity's role in Article 3 ECHR.” Strasbourg Observers. January 20, 2020. https://strasbourgobservers. com/2015/10/08/bouyid-and-dignitys-role-in-article-3-echr/.

McCrudden, Christopher. "Human Dignity and Judicial Interpretation of Human Rights." The European Journal of International Law 19, no. 4 (2008): 655-724. https://doi.org/10.1093/ejil/chn043.

Genocide Network Secretariat EUROJUST. 2014. „Prosecuting War Crimes of Outrage upon Personal Dignity Based on Evidence from Open Sources - Legal Framework and Recent Developments in the Member States of the European Union.” January 15, 2020. http://www.eurojust.europa.eu/doclibrary/ genocide-network/KnowledgeSharing/Prosecuting\%20war\%20crimes $\% 20$ of $\% 20$ outrage $\% 20$ upon $\% 20$ personal $\% 20$ dignity $\% 20$ based $\% 20 \mathrm{on} \% 20 \mathrm{ev}$ idence\%20from\%20open\%20sources\%20(February\%202018)/2018-02_ Prosecuting-war-crimes-based-on-evidence-from-open-sources_EN.pdf.

${ }^{60}$ Christopher McCrudden, "Human Dignity and Judicial Interpretation of Human Rights," 723. 